\title{
Drivers of Globalisation of Higher Education over the Last 70 Years
}

\author{
Andrew J. Deeks
}

\section{Introduction}

The 70th anniversary of the International Association of Universities provides an opportunity to look back over the post-World War II era, and to reflect on the drivers that have led to the international higher education environment we experience today. The anniversary also provides an opportunity to look forward and to consider how such a globalised system of universities might contribute to future society.

Since the IAU was set up under the auspices of UNESCO just five years after the end of the Second World War and the establishment of the United Nations, we have seen an explosion in the number of universities, the number of people participating in higher education, and the mobility of faculty and students, all contributing to the development of a truly global university ecosystem.

Many drivers have contributed to this development. This chapter will consider in particular the emergence of English as a lingua franca, the development of cheap and convenient international transport, the globalisation of industry and commerce, the massification of higher education, the development of the internet and social media, and the emergence of international university rankings.

If human society is to have a long-term future, we must work together to address the challenge of creating a sustainable global society. A globalised university ecosystem represents the best opportunity for moving this agenda forward, as universities, ideally, stand outside the political, nationalistic, and religious dogma that influence decision-making and cooperation at state level.

\footnotetext{
A. J. Deeks (凶)

University College Dublin, Dublin, Ireland

e-mail: andrew.deeks@ucd.ie

(C) The Author(s) 2021 


\section{Language}

While scholarship has been associated with civilisations and cultures since the beginning of recorded history, the university tradition and the research culture of free enquiry and open publication of research papers emerged in Europe. Up until the Second World War, scholars typically published in one of the major European languages (here including Russian as a European language). During the war, much of Europe and Russia had suffered great social, economic and infrastructure loss, and in the aftermath went through a decade of rebuilding. The USA, on the other hand, avoided much of this loss and was able to recruit leading European scientists and engineers to exploit the technological advances made by both sides during the war effort. Coupled with a booming economy powered by cheap oil, the USA became the primary driver of the world research effort, and English became the dominant language for publication of research results. By the time European countries were again competitive in the research space, and other regions started paying more attention to research and development, the pre-eminence of English as the language of research and technology had been established. At the same time, the economic strength of the United States, together with economic re-emergence of the UK and the colonial legacy of English use throughout the subcontinent and much of Africa, led to English becoming the lingua franca of global trade and commerce. Consequently, English has also become the dominant language of global education.

Not only are there now more English speakers in the world than there are speakers of any other language, but there are also around twice as many speakers of English as a second language than there are native speakers (Ethnologue 2020). No other language has more second language speakers than first language speakers. There is nothing about English that makes it particularly suitable to be a lingua franca, and that English has emerged to be this lingua franca is an accident of history more than anything else. Nevertheless, the rise of a language which is widely spoken and read by educated people around the world has been a significant driver and enabler of the

globalisation of higher education. Universities around the world who wish to attract students from outside their home country now offer programmes in English and hire faculty who can teach and publish in English.

\section{Transport}

Although intercontinental transport has been with us for centuries, for much of that time, such travel involved significant time and danger. Within the 70 years of the IAU, we have seen a transformation in our ability to travel the world. Over that time, the cost, reach, comfort and safety of air transport have all dramatically improved. From very few commercial flights at the end of the second world war to some 310 million aircraft passengers per year by 1970 , and then to 4.233 billion passengers a year by 2018 (The World Bank 2018), the number of people travelling between 
countries has increased exponentially. Although the COVID-19 pandemic has put a temporary halt to this expansion, the infrastructure and economics of the global aviation system remain intact, and affordable and convenient intercontinental travel is with us to stay.

From a global education perspective, students and their families can easily travel between countries to access higher education, and the cost of travel relative to the overall cost of participating in higher education has become a smaller and smaller consideration.

\section{Globalisation of Industry and Commerce}

The reduction in the cost of transport, not just for passengers, but also for freight, and the increase in convenience and reduction in cost of communication across the world were also enablers of a globalisation of the world economy. Since 1950 the value of exported goods has increased by a factor of more than 30, a compounded annual increase averaging $6 \%$ over the entire period, and the average proportion of country GDP that is exported has moved from under $10 \%$ in 1950 to over $25 \%$ now (OrtizOspina and Beltekian 2018). Even these figures do not fully capture the massive change which has occurred, as the increase in GDP around the world over this time has been increasing, driven by growth in the service sector. In most countries, the manufacturing sector has dramatically decreased as a proportion of GDP since 1950 . Globalisation of manufacturing has dramatically decreased the cost of products to the consumer and reduced the proportion of people employed in the production of goods. However, the global logistics industry associated with moving manufactured and agricultural goods around the world has grown accordingly, while improved communication and decreased cost of travel has meant that the service sector is also increasingly globalised.

Associated with this globalisation has been the rise of major multinational companies, particularly in the resource sector, the technology sector and certain parts of the services sector. Increasingly, these companies recruit employees globally, and they are looking for graduates with a global view and international experience. Students see that taking part of their higher education outside their home country provides an advantage when seeking employment with these multinational companies. For their part, the multinational companies have an interest in engaging with higher education institutions so they can access quality graduates with an understanding of their home market.

These multinational companies are also keen to tap into the research being done at universities around the world and can play the role of a catalyst in bringing together research teams from different universities spread across different countries. In addition, domestic companies looking for opportunities abroad may be keen to engage with universities to identify students from their target markets for potential graduate employment. 


\section{Massification of Higher Education}

In 1950, just $3.4 \%$ of young people in the UK went on to higher education. That number has now increased to around 50\% (Department of Education 2019). This growth in higher education participation is reflected around the world. As mechanisation and the growth of digital technology has reduced the number of jobs available to those with lower levels of education, and improving income levels have allowed families to keep children in education longer, the number of children completing primary school, secondary school, and now higher education has increased dramatically over these seventy years.

Despite this increase in the participation rate, the preparation and ability of the incoming students remain similar, and the level of achievement of graduates has been maintained. However, in a competitive job market, many students look for opportunities to make themselves stand out from the crowd. Undertaking studies abroad is one way students can do this. If they come from a non-English-speaking country, studying abroad in an institution or country where English is spoken provides a way of distinguishing oneself, while also building English skills.

At the same time, the massification of the higher education system has placed increased strain on the government funding of higher education. While governments could generally afford the costs of educating 3.4\% of their population to undergraduate degree level, as participation levels approached (and in some cases exceeded) $50 \%$, many governments found it necessary to cut the support they were giving to universities and to increase the financial burden carried by the students. For political reasons, most governments prescribe or cap the amount paid by domestic students towards their education, while at the same time fixing state funding. However, many governments allow universities to set their own international student fees, so international students are often charged a fee that provides the university with a premium over and above the cost of providing the education.

Consequently, the massification of higher education has generated incentives for students to undertake studies outside of their home country, and for universities to recruit students from outside their home country. The provision of higher education services to students who wish to study abroad has become a significant industry, one which has contributed to the globalisation of higher education.

\section{The Internet and Social Media}

The development of the internet and the worldwide web, together with fixed and mobile data services spanning the world, has greatly raised awareness of opportunities to travel to other places and to undertake studies at universities in other countries. Coupled with the widespread use of English on websites, students can explore the many opportunities available to them with an ease that would have been unthinkable before these developments. 
Social media allows students who are undertaking studies abroad to remain in touch with their friends and families and to share their experiences with other students who might be considering studying abroad. Video conferencing and messaging services mean that students studying abroad can stay in touch with their loved ones and friends in a very intimate way, and so the fear of loneliness and losing the connection that once existed is mitigated.

From a research perspective, the internet allows researchers from around the world to collaborate and share results with an immediacy which was not previously possible and allows widespread and convenient access to research papers, particularly those written in English. Prospective research students can easily identify the leaders in a field they are interested in and contact those people directly to seek opportunities to undertake studies under their supervision, no matter what part of the world they might be resident in. This connectivity also facilitates the mobility of researchers and faculty, and the organisation of international meetings and conferences, which consequently have become much more numerous in recent times.

The internet and widespread availability of connection to it have therefore driven globalisation of higher education over this period, increasing the diversity of faculty at universities around the world and increasing the number of students studying outside their home country. It has also improved the experience of those involved in this mobility, allowing them to stay connected to their home communities.

\section{Rankings}

Although relatively recent in their establishment (the Academic Ranking of World Universities was established in 2003), world rankings of universities have had a dramatic impact on the global higher education environment. Prior to the establishment and popularisation of these rankings, universities generally looked to other universities in their geographic location as comparators, while prospective students selected universities based on their historical reputations. The international student market in some regions allowed some movers to present themselves at a level which their domestic reputation would not have supported.

By purporting to rank universities in an order which represented the 'best', rankings were quickly seized on by prospective students and parents as an easy way of comparing universities. They also became a benchmark for prospective faculty weighing up employment options. Because of the potential impacts of these phenomena, but also because the ranking brought out the competitive spirit in university leadership, alumni and stakeholders, rankings quickly became an obsession, not just for universities, but also for governments.

While there are now a number of rankings that have a global impact, each of these rankings uses basically the same metrics, albeit with differences in weights: measures of research productivity and impact; student: faculty ratio; proportion of international students; proportion of international faculty; engagement with industry/industry funding; and reputation amongst academics and employers globally. 
The nature of the metrics is such that the global visibility and reach of a university is one dominant factor in ranking performance, while another is research performance, where research performance is measured primarily through the number of publications in 'international' English language journals and the number of citations by other authors in the same journal set.

Rankings incentivise universities to benchmark themselves against similar universities around the world, recruit the best faculty from around the world (with research performance being the primary criteria), increase their number of international students, and increase their visibility in all regions of the world. The desire to increase visibility has led many universities to increase their participation in international university networks and to establish more bilateral institutional partnerships.

From a globalisation perspective, the increased engagement of universities globally has led to increased opportunities for student and employee mobility and increased visibility of and support for those opportunities. The rankings' use of citations metrics and reputation surveys weighted in favour of reputation outside a university's home country have increased institution support for collaboration undertaken between research groups based in different countries. Combined with the greater awareness brought about by the internet and the increased ease and reduced expense of travelling between countries, international research collaboration has flourished.

Of course, the rise of rankings has caused problems too. By their nature, the rankings incentivise all universities to pursue the same goals (and in many cases the same professors), driving universities towards the comprehensive research-intensive model. Many argue that national interests are better served with a tiered higher education system, and having universities competing against each other for global rankings that are not linked to national goals, or indeed the personal goals of the students, may be counterproductive.

Nevertheless, the perceived prestige of having universities ranked in the top 100 in the world has incentivised many national governments to invest additional funding into targeted institutions in order to improve their ranking. This is often positive from the perspective of bringing additional money into the institutions, particularly money to support research. However, reporting requirements imposed by these governments may also lead to the university leadership adopting a very narrow focus and losing sight of the broader role a university should play in its community and national contexts.

\section{Recent Setbacks}

From the sixties through to the first decade of this century, there was a continuous increase in the level of globalisation of national economies, leading to increases in average material well-being of people around the world, higher participation rates in higher education and greater mobility of university students and faculty.

The Global Economic Crisis of 2008 and the recession that followed triggered a decade of questioning of the value of globalisation and a resurgence of national- 
ism. When recession hit, people noticed the number of jobs that had disappeared in manufacturing and the number of national industries that had been lost as a result of cheaper imported products, and some blamed globalisation for their economic situation. In doing so, they forgot about the prosperity globalisation had brought, which they had come to take for granted.

National politics in many countries have pandered to this push-back against globalisation, leading to an increased division between those who understand the benefits of globalisation and those who see it as a threat. However, as nationalist forces have come into power in some countries, the futility of trying to reverse globalisation is becoming increasingly clear. Politicians have to change the story-Brexit moved from being an anti-immigration, anti-Europe campaign to stop free movement of people into the country and to invest money 'sent to Europe' back into the national economy (the basis on which the referendum was fought) into a new 'Global UK' story where the UK will be a champion of world free trade.

The 2020 COVID-19 pandemic has illustrated the extent to which we now live in a single global society, as within three months of first being recognised, the novel coronavirus was spread throughout the globe by the global mobility of the world population. The pandemic has also brought challenges to globalisation as this mobility is drastically reduced and as economies have been shut down in a bid to tackle the virus. While temporarily halting the face-to-face interactions on which relationships are based, the loss of mobility has not reduced other aspects of globalisation in any significant way. Digital communications technology allows education and research to continue in partnerships which are now maintained at a distance, while global supply lines continue to function to deliver food, medical supplies and other goods and services to consumers around the world. The long term effect of the pandemic on the cost and convenience of international travel has yet to become clear, but given that the infrastructure remains in place and there are sufficient skilled workers for the industry, it is likely that once international travel can again be undertaken without public health concerns, the industry should bounce back quickly.

\section{The Future-Addressing Global Challenges Together}

The globalisation of industry and commerce has been built on the back of cheaper transport of goods and people, together with ubiquitous communication and information technology systems. Building, operating and maintaining the infrastructure which underpins these enablers currently relies on exploiting the mineral resources of the Earth (primarily metals, oil and gas). Developing technologies that have allowed the extraction of these resources from greater depths and from lower grade deposits than was previously possible, has, to this point in time, avoided a shortage of these resources. However, such technologies require greater amounts of energy to be invested in the extraction, and most of this energy is currently supplied by fossil fuels. Similarly, we can feed the increasing population of the Earth largely because agricultural technologies are allowing us to get greater yield from farmland, and 
to bring into use land which was previously unsuitable for agricultural purposes. Again, the cost of this increased productivity is more energy invested per $\mathrm{kg}$ of food produced, with most of this energy currently coming from fossil fuels.

As mineral resources are unequally distributed between nations, the reliance of our global society on these resources generates fundamental inequities in the distribution of wealth throughout the world, which is reflected in inequality of educational and health outcomes. Coupled with competing political and religious ideologies, this sets the stage for intranational and international conflicts of various types.

It is by nations recognising that we can only achieve a sustainable future through addressing these global challenges together that we can continue to flourish as a society. In a globalised world, universities are ideally positioned to lead this agenda, as, within universities facts, data and ideas are put ahead of political, nationalistic and religious dogma, and colleagues from different cultural backgrounds work together with a common purpose. These universities also educate the leaders of the future, and we have the opportunity to educate these leaders to understand the responsibility they will have to work together with other leaders of their generation to advance the creation of a sustainable, healthy and equitable global society.

Higher education has come a long way in the last 70 years, and we are now part of a truly global higher education ecosystem. We are uniquely positioned to contribute to the building of a global human society which is sustainable and equitable, and which promotes the health and well-being of all members of this society, and the International Association of Universities provides a vehicle through which our contributions can be coordinated.

\section{References}

Department of Education. (2019). Participation rates in higher education. Retrieved from: www.gov.uk/government/statistics/participation-rates-in-higher-education-2006-to-2018 (13.07.2020)

Ethnologue. (2020). What is the most spoken language?. Retrieved from: www.ethnologue.com/ guides/most-spoken-languages. (13.07.2020)

Ortiz-Ospina, E., \& Beltekian, D. (2018).Trade and globalization. Our World in Data. Retrieved from: https://ourworldindata.org/trade-and-globalization (13.07.2020)

The World Bank. (2018). Air transport, passengers carried. Retrieved from: https://data.worldbank. org/indicator/IS.AIR.PSGR (13.07.2020)

Andrew J. Deeks has been the President of University College Dublin since January 2014. He is a member of the Administrative Board of the International Association of Universities, a member of the Executive Committee of Universitas 21, and a Council member of both the European Universities Association and the Irish Universities Association. He is a Fellow of the Irish Academy of Engineering, the Institution of Engineers Ireland and the Institution of Engineers Australia. 
Open Access This chapter is licensed under the terms of the Creative Commons Attribution 4.0 International License (http://creativecommons.org/licenses/by/4.0/), which permits use, sharing, adaptation, distribution and reproduction in any medium or format, as long as you give appropriate credit to the original author(s) and the source, provide a link to the Creative Commons license and indicate if changes were made.

The images or other third party material in this chapter are included in the chapter's Creative Commons license, unless indicated otherwise in a credit line to the material. If material is not included in the chapter's Creative Commons license and your intended use is not permitted by statutory regulation or exceeds the permitted use, you will need to obtain permission directly from the copyright holder. 